Coal Board; Prof. C. G. C. Chesters, Department of Botany, University of Nottingham; Dr. A. Clow, British Broadcasting Corporation; The Right Hon. the Earl of Crawford and Balcarres; Mr. A. A. Fulton, chief hydraulic engineer, North of Scotland HydroElectric Board; the Right Hon. the Earl of Haddington; Dr. J. Heslop Harrison, lecturer in the principles of plant taxonomy, University of London; the Right Hon. the Earl of Home, P.C., Minister of State, Scottish Office; Dr. D. B. McIntyre, lecturer in petrology, University of Edinburgh; Mr. B. G. McLellan, formerly director of the Scottish Seaweed Research Association; Sir James Irvine Masson, formerly vice-chancellor of the University of Sheffield; Dr. A. D. Merriman, registrar-secretary of the Institution of Metallurgists, London; Dr. A. R. Mitchell, lecturer in applied mathematies, University of St. Andrews ; Dr. A. T. Phillipson, deputy director and head of the Physiology Department, Rowett Research Institute, Bucksburn, Aberdeenshire; $\mathrm{Mr}$. K. S. M. Rae, officer-in-charge, Oceanographic Laboratory, Edinburgh; Dr. Fdith P. Smith, lecturer in botany, Lniversity College, Durdee; Dr. J. T. Stamp, head of the Veterinary Department and veterinary investigation officer, Edinburgh and East of Scotland College of Agriculture; Dr. D. M. Steven, lecturer in zoology, University of Edinburgh; Prof. M. M. Swann, Department of Natural History, University of Edinburgh ; Prineipal T. M. 'Taylor, vice-chancellor of the University of Aberdeen; Prof. W. L. Weipers, Department of Veterinary Surgery, University of Glasgow ; Dr. L. H. Wells, senior lecturer in physical anthropology, University of Edinburgh.

\section{Meteorological Expedition to the British West Indies}

Prof. P. A. SHEPPARD, of the Department of Meteorology, Imperial College of Science and Technology, London, has recently left the United Kingdom to lead a small meteorological expedition from his department to Anegada (lat. $18^{\circ} \mathrm{N}$., long. $64^{\circ} \mathrm{W}$.) in the British Virgin Islands, British West Indies. The expedition, in which tho National Institute of Oceanography is collaborating, is planning to study for about a month the transfer of momentum, heat and wator vapour from the ocean into the Trade Wind air, to relate these transfers with the vertical variation of mean wind speed and direction in the first kilometre or two of the atmosphere and with the pattern and structure of Trade Wind cloud, mainly cumulus. This expedition follows an earlier expedition to the Scilly Isles during January 1951. There, momentum transfer processes were studied in the variable westerlies of middle latitudes, and the results indicated that the classical concept of the terrestrial friction layer, a layer half a kilometre or so in thickness, in which turbulence and momentum transfer drop off to zero at the top of the layer, needed revision. The results could be interpreted on the assumption that the momentum transfer was maintained or even increased with height by means of turbulence of moderate scale which was found to exist in the air. Unlike the classical boundary layer beneath a uniform stream of air, the wind speed in the westerlies increases with height up to the level of the tropopause, not through friction at the underlying ocean surface but because of the temperaturo drop towards higher latitude. In the Trade Winds a similar temperature drop causes easterlies near the surface to give way to westerlies (anti-Trades) aloft. This difference between Trade Winds and westerlies is likely to lead to markedly different patterns of momentum transfer in the two fields, a differenco which if substantiated must be important in the understanding of the general circulation of the atmosphero. Anegada is a small low-lying island in a Trade Wind area, and the expedition will use it as a fixed platform to observe the variation in wind from one five minutes to the next, that is, the moderate-scale turbulence, in the first kilometre or two of the Trade air, using balloons. Time-lapse photography of the clouds will also be undertaken. The Woods Hole Oceanographic Institution in Massachusetts will collaborate with the Imperial College expedition by using an aircraft to take observations of cloud structure in the same region at the same time.

\section{Photoelectric Studies of the Night Sky Light}

A pAper by Masaaki Huruhata on "Photoelectric Studies of the Night Sky Light" has been published in Tokyo Astronomical Observatory Reprints, No. 89 (reprinted from the Report of Ionosphere Research in Japan, 6, No. 1 ; 1952), which describes the method of study of the horizontal drift of the night sky. The measured emission of the infra-red radiation between 8500 and $11000 \mathrm{~A}$. was identified as due to the $\mathrm{OH}$ ion; this radiation is so strong that it can be easily measured over the whole sky without suffering from the effects of bright star-light. The instrument consists of a photoelectric photometer furnished with a cæsium cell, the current being amplified by the electrometer tube. An infra-red filter placed in front of the photocell cuts out the visual light shorter than $8500 \mathrm{~A}$. Observations were carried out at Yawatano, Skizuoka-ken, and the results are plotted for each hour for various periods between January 1, 1949, and December 11, 1950. On most nights the drift of intense or weak clouds of the night sky could be recognized, the direction of drift being mostly from north-north-east to southsouth-west or in the opposite direction, and this direction is perpendicular to the geomagnetic parallel. On December 23, 1949, the velocity of the drift was estimated to be $1,000 \mathrm{~km}$./hr., but this appears to be exceptional and several hundred $\mathrm{km}$. $/ \mathrm{hr}$. seems to be the normal speed. It is remarkable that the speed of the southward drift averages about 20 per cent more than that of the northward drift. Attempts were made to find some correlations between drift and the position of the moon, on the theory that wind in the upper regions of the atmosphere-about $300 \mathrm{~km}$. high-might be caused by tidal movements, but none could be found, nor could any correlation be found between the drift and the ionospheric and geomagnetic disturbances observed in Japan proper.

\section{Study of Forest Seeds in Sweden}

AN article by Einar Huss, entitled "Methods used in the Swedish Forest Research Institute in Seed Experiments", has been published in Reports of the Forest Research Institute of Sweden (Meddelanden fràn Statens Skogsforsliningsinstitut, 40,$53 ; 1952)$, in which it is stated that during the past few yoars, owing to the growing interest in forest culture in Sweden, a thoroughgoing study of questions touching the appropriate methods of treating forest seed and the characters determining the effect on plant results has been undertaken. There were also the problems of supplying the forest industry with enough seed, because of the greatly increased demand, and the necessity, owing to this increased demand, of producing the bost possible quality of seed, which is a commercially expensive commodity. There are few 